\section{Desarrollo profesional continuo, ¿de qué estamos hablando?}

Helios Pardell Alentá

En los últimos tiempos, el término desarrollo profesional continuo (DPC) se ha incorporado de lleno al mundo profesional médico. Sin embargo, su interpretación en la práctica dista mucho de ser uniforme $y$, con frecuencia, los distintos agentes lo utilizan con finalidades bien distintas, cuando no claramente contrapuestas. De ahí que resulte necesario un esfuerzo de clarificación, que ayude a la aplicación más racional y coherente del concepto del DPC.

\section{¿Qué es el DPC?}

Tanto en las primeras formulaciones internacionales por parte de los autores que lo introdujeron, como en las definiciones de la Federación Mundial de Educación Médica o la del Comité Permanente de Médicos Europeos, el DPC se entiende fundamentalmente como un proyecto de carácter individual del médico, enmarcado en el ideario del profesionalismo, que tiene sus raíces en el compromiso ético-profesional de mantenerse competente durante su vida activa, con objeto de ofrecer en todo momento una actuación adaptada a las corrientes cientificomédicas del momento y al sistema sanitario en el que se desenvuelve profesionalmente. Sus postulados arrancan de los de la formación médica continuada tradicional, a los que trascienden en algunos ámbitos que no eran objeto preferente de los esquemas clásicos de los programas formativos y, como elemento claramente diferencial, incorpora el componente reflexivo descrito inicialmente por Schön, que incluye la autoformación a partir de la reflexión en y sobre la práctica.

De hecho, si partimos del concepto más aceptado de carrera profesional (CP) en la bibliografía

\section{Continuing Professional Development. What are we talking about?}

The term Continuing Professional Development $(C P D)$ has recently come to the fore in the world of medical profession. Nevertheless, in practice it is interpreted in anything but a uniform manner and the different agents involved often use it for very different, and even clearly opposing, purposes. Therefore, some clarification seems to be needed in order to achieve a more rational and coherent application of the concept of CPD.

\section{What is CPD?}

In both the first international formulations by the authors that introduced the concept and the definitions drawn up by the World Federation for Medical Education or the Standing Committee of European Doctors, CPD is essentially understood to be a project undertaken on an individual basis by each physician, as part of the ideology of the profession. It has its roots in the ethical-professional commitment to keep up to date and therefore competent for lifelong, so as to be able to act in accordance with the updated scientific-medical tendencies and in tune with the health service in which the professional is working. Its underlying assumptions stem from those of traditional continuous medical education, although it goes beyond these traditional propositions in some areas that were not considered to be primary aims in the classic educational programmes. One element that clearly distinguishes it from its predecessor is the consideration of the reflexive component initially described by Schön, which includes self-education based on thinking in and on practice.

In fact, if we set out from the concept of Professional Career (PC) that is most widely accepted in
Responsable DPC-FMC. Fundación Educación Médica

E-mail

hpardell@comb.es 
internacional como la progresión competencial y experiencial de un profesional a lo largo de su vida, no existen grandes diferencias con el DPC. Pero, en nuestro país, la formulación de la CP se ha hecho a partir de una base eminentemente sindical, con sus repercusiones laborales y salariales correspondientes, lo que la ha circunscrito al ámbito de la organización en la que el profesional presta sus servicios y, con el tiempo, se ha visto desnaturalizada, al convertirse en un baremo de antigüedad ligeramente modificado.

La Ley de Ordenación de las Profesiones Sanitarias lo entiende como 'el reconocimiento público, expreso y de manera individualizada, del desarrollo del profesional sanitario por lo que se refiere a los conocimientos, la experiencia en las tareas asistenciales, docentes y de investigación, así como en el cumplimiento de los objetivos asistenciales y de investigación de la organización en la que presta sus servicios'.

Si esta última definición parece clara, la cosa se complica cuando se la compara con la que de la $\mathrm{CP}$ hace la Ley del Estatuto Marco: 'el derecho del profesional a progresar, de forma individualizada, como reconocimiento de su desarrollo profesional por lo que se refiere a los conocimientos, la experiencia y el cumplimiento de los objetivos de la organización en la que presta sus servicios'. Y, por si fuera poco, todavía aumenta más la confusión cuando cada una de las dos leyes mencionadas introduce niveles de progresión, tanto para el DPC como para la CP, lo que contribuye a hacer más difíciles de diferenciar ambos conceptos.

\section{EI DPC en la práctica}

De todo ello se deriva que, en la práctica, cuando se intenta plasmar el DPC en una realidad concreta, no sean pocos quienes caigan en la tentación de verlo como un nivel superior de la $\mathrm{CP}$ o, lo que es peor, como una $\mathrm{CP}$ bis, que venga a remediar la frustración que ésta ha generado en el colectivo de médicos empleados de los servicios públicos de salud de las comunidades autónomas a los pocos años de su implantación.

$\mathrm{Ni}$ que decir tiene que en el trasfondo de la cuestión subyace el dilema en el que se hallan sumidos la gran mayoría de los médicos de hoy, que no acaban de dilucidar si son profesionales auténticos, con todo lo que ello comporta, o meros em- the international literature, that is, the progression made by a professional in different skills and experiences throughout his or her working life, then it does not appear to be so different from CPD. In our country, however, $P C$ has been formulated mainly on a trade-unionist basis, with the consequent occupational and salary-related repercussions. This has limited it to the scope of the organisation in which the professional offers his or her services and, with the passage of time, it has been distorted and become a slightly modified scale of seniority.

The Spanish Ley de Ordenación de las Profesiones Sanitarias (Health Professions Regulation Act) understands it to be 'the public, express and individualised recognition of the development of the health professional as regards knowledge, experience in health care, teaching and research activities, as well as in satisfying the health care and research objectives set by the organisation the professional works for'.

Although this last definition seems quite clear, things get a bit more complicated when we compare it with the definition of Professional Career given by the Regulatory Framework, i.e. "the right a professional has to progress, on an individual basis, as acknowledgment of their professional development in matters concerning knowledge, experience and satisfaction of the objectives of the organisation he or she works for". And as if that weren't enough, even more confusion arises when each of the two above-mentioned laws introduces levels of progression, both for the $C P D$ and for $P C$, which only makes it even more difficult to distinguish between the two concepts.

\section{CPD in practice}

From all this it can be seen that, in practice, when attempts are made to embody CPD in a concrete reality, a common mistake is to fall into the temptation of seeing it as a higher level of PC or, worse still, as a kind of PC-b that will put an end to the frustration that, just a few years after its implementation, $P C$ has generated among physicians employed by public health services within the Autonomous Communities.

It goes without saying that at the root of the issue lies the dilemma in which most physicians find themselves immersed today, i.e. it is not altogether clear whether they are true professionals, with all that such a denomination entails, or simply em- 
pleados, con carácter estatutario, de los servicios públicos autonómicos de salud.

$\mathrm{Si}$, como venimos propugnando insistentemente, los médicos y sus organizaciones profesionales deben reformular el ideario del profesionalismo e incorporarlo plenamente a su práctica cotidiana, no cabe ninguna duda de que el DPC adquiere todo su significado como el esfuerzo individual para mantenerse competente y progresar a lo largo de su vida. Y en este contexto, se ve claro que el DPC es responsabilidad prístina del médico, que lo lleva con él, a modo de mochila, durante su vida profesional, utilizándolo para distintos propósitos promocionales, entre ellos, también, para encontrar las mejores oportunidades laborales en un mercado de trabajo libre y abierto.

Todo esto cambia de sentido cuando nos situamos en un panorama del médico que se considera básicamente empleado, que reclama su formación continuada y, por extensión, su DPC, como un derecho que le debe satisfacer el empleador. De ahí todo el entramado burocrático y reglamentario para asegurar al máximo la equidad en la asignación de niveles, a los cuales pueden acceder todos los médicos empleados de las instituciones públicas, que han diseñado su CP a partir de los postulados de la Ley del Estatuto Marco.

Adentrándonos un poco más en esta situación, en una interpretación límite podríamos decir que DPC hay tantos como médicos, mientras que CP hay tantas como instituciones empleadoras (o grupos o sistemas empleadores).

\section{Opciones de futuro}

Si así lo entendemos, no ha de costar demasiado empezar a ordenar la situación, a condición de que todos aceptemos que la CP, con sus niveles, repercute de manera directa sobre las condiciones laborales y salariales del médico, mientras que el DPC no. No de manera directa, porque claro está que lo hace de manera indirecta, dado que puede y debe incorporarse como un componente en los baremos de progresión de la $\mathrm{CP}$, además de sus utilidades en el plano profesional que, lógicamente, no tiene aquélla.

A partir de ahí, tampoco debiera resultar difícil de aceptar que la CP cae en el campo de negociación de los sindicatos con los empleadores, públicos y privados, mientras que el DPC lo ployees, albeit of a statutory nature, of the autonomic public health services.

If, as we have insistently advocated, physicians and their professional organisations are to reformulate the way of thinking of the profession and fully incorporate this ideology into their daily practice, then there can be no doubt whatsoever that CPD must be taken as the individual effort made to keep oneself up to date, and therefore competent, and to progress in one's working life. And in this context, it also becomes clear that CPD is the physician's responsibility and that it is something he or she must bear, like a kind of backpack, throughout their entire working life, and is something that will be used for different promotional purposes, such as seeking the best job opportunities in a free and open job market.

All this takes on a different meaning when we look at things from the perspective of the physician as essentially an employee, who claims his or her continuous education and, by extension, his or her CPD as a right that the employer must satisfy. This is what accounts for the whole network of bureaucracy and regulations that exist to ensure, as far as possible, equality when it comes to assigning the levels that can be reached by all physicians employed by public institutions, which have designed their PC based on the assumptions of the Estatuto Marco Act.

If we go a little further into this situation and take the most extreme interpretation, we could say that there are as many CPDs as there are doctors, whereas the number of PCs is the same as the number of employing institutions (or employing groups or systems).

\section{Options for the future}

If understood in this way, it shouldn't be too difficult to begin to put the situation in order, provided that we all accept that PC, with its different levels, has a direct effect on the physicians' occupational and salary-related conditions, whereas the CPD does not have such repercussions, or at least not directly. It is, of course, obvious that it does exert an indirect influence due to the fact that it can and must be incorporated as a component of the scale used to measure the progression of the $P C$, as well as its being useful at a professional level, and this is not the case of the PC.

From there on, it should not be difficult to accept the notion that PC lies within the field of negotiations between trade unions and employers, both pub- 
hace en el de las organizaciones profesionales y los agentes reguladores. Lo que, en este contexto, resulta necesario es que los agentes involucrados en el DPC, muy especialmente las organizaciones profesionales (sociedades científicas y, más concretamente, colegios de médicos), sepan encontrar las vías de utilización práctica que he esbozado de forma sumaria, fundamentalmente por lo que se refiere a los distintos ámbitos de promoción individual (titulaciones, credenciales y CP) y a los de autorregulación (registro de entrada, reglamento, definición de límites competenciales y revalidación). Si no lo hacen, cabe esperar que la fuerza de los incentivos económicos de la $\mathrm{CP}$ acabe por desdibujar del todo el perfil propio del DPC y se haya perdido una oportunidad de oro para reorientar el futuro de la profesión.

Esperemos que de la situación de confusión actual alrededor del DPC, cada uno de los actores (médicos, organizaciones profesionales, sindicatos, empleadores y agentes reguladores) sepa sacar ideas que le ayuden a clarificar sus posiciones. Si así lo hacen, bien habrá valido la pena la zozobra que atravesamos, a condición de que cada uno se responsabilice y comprometa y, en un esfuerzo de visión de futuro y de servicio a los demás, trate de no invadir campos ajenos, trabajando en colaboración para bien del sistema sanitario, de la profesión y, en definitiva, de la sociedad. lic and private, while CPD stands within the area of professional organisations and regulatory agents.

In this context, the players involved in $C P D$, and more especially the professional organisations (scientific societies and medical associations), must be able to find ways to put it to practical use, as I have briefly outlined. This is especially true with regard to the different areas of individual promotion (qualifications, credentials and $P C$ ) and selfregulation (entry register, regulations, definition of the limits of competencies and revalidation). If they do not do so, we can suppose that the force of the economic incentives of $P C$ will end up blurring the contour of CPD completely and we will have missed a golden opportunity to realign the future of the profession.

We hope that, from within the current state of confusion surrounding $C P D$, each of the stakeholders (physicians, professional organisations, trade unions, employers and regulatory agents) will be able to come up with ideas that help them clarify their positions. If they manage to do so, it will have been worthwhile crossing this period of uncertainty we now find ourselves in. However, each of those involved must take on his or her responsibilities and commitments and, with a view to a brighter future and the desire to offer their services to others, try to avoid invading other fields by working in collaboration for the good of the health care system, the profession and, ultimately, society itself. 